\title{
The Topography of Ganglion Cell Production in the Cat's Retina ${ }^{1}$
}

\author{
C. WALSH ${ }^{*}$ and E. H. POLLEY ${ }^{2}$ \\ * Committee on Neurobiology, The University of Chicago, 947 East 58th Street, Chicago, Illinois 60637 and Departments of Anatomy, \\ Ophthalmology and Neurosurgery, The University of Illinois at the Medical Center, Chicago, Illinois 60680
}

\begin{abstract}
The ganglion cells of the cat's retina form several classes distinguishable in terms of soma size, axon diameter, dendritic morphology, physiological properties, and central connections. Labeling with $\left[{ }^{3} \mathrm{H}\right]$ thymidine shows that the ganglion cells which survive in the adult are produced as several temporally shifted, overlapping waves: medium-sized cells are produced before large cells, whereas the smallest ganglion cells are produced throughout the period of ganglion cell generation (Walsh, C., E. H. Polley, T. L. Hickey, and R. W. Guillery (1983) Nature 302: 611-614). Large cells and medium-sized cells show the same distinctive pattern of production, forming rough spirals around the area centralis. The oldest cells tend to lie superior and nasal to the area centralis, whereas cells in the inferior nasal retina and inferior temporal retina are, in general, progressively younger. Within each retinal quadrant, cells nearer the area centralis tend to be older than cells in the periphery, but there is substantial overlap. The retinal raphe divides the superior temporal quadrant into two zones with different patterns of cell addition. Superior temporal retina near the vertical meridian adds cells only slightly later than superior nasal retina, whereas superior temporal retina near the horizontal meridian adds cells very late, contemporaneously with inferior temporal retina. The broader wave of production of smaller ganglion cells seems to follow this same spiral pattern at its beginning and end. The presence of the area centralis as a nodal point about which ganglion cell production in the retinal quadrants pivots suggests that the area centralis is already an important retinal landmark even at the earliest stages of retinal development.
\end{abstract}

Received June 4, 1984; Revised August 27, 1984;

Accepted August 28, 1984

\footnotetext{
${ }^{1}$ We thank La Donna Williams for typing the manuscript, Steve Price for preparing the figures, Jenny Hunter for technical assistance, Jamie Allen for helping with the mathematical analysis of sectioned nuclei, T. L. Hickey, who provided the tissues used in this study and collaborated in earlier stages of the project, and R. W. Guillery, who provided invaluable support and criticism at all stages of this study.

This work was supported by National Institutes of Health Grants NS-14823 (R. W. Guillery), EY-01338 (T. L. Hickey), and EY-04593 (E. H. P.), and by United States Public Health Service Grant PHS 5 T32 GM07281 (C. W.). Part of this work was done while C. W. held Deutscher Akademischer Austauschdienst fellowship at the Max-Planck-Institut für Hirnforschung in Frankfurt, Federal Republic of Germany, and he thanks W. Singer and H. Wässle for their support and encouragement.

${ }^{2}$ To whom correspondence should be addressed, at Department of Anatomy, the University of Illinois at the Medical Center, P. O. Box 6998, Chicago, IL 60680 .
}

This sequence of ganglion cell production differs markedly from that seen in the retinae of nonmammalian vertebrates, where new ganglion cells are added as concentric rings to the retinal periphery, and also bears no simple relationship to the cat's retinal decussation line. However, it can be related in a straightforward manner to the organization of axons in the cat's optic tract, suggesting that the fiber order in the tract represents a grouping of fibers by age.

The ganglion cells of the cat's retina have been subdivided in terms of perikaryal size, dendritic morphology, functional properties, and axon diameter, and these classifications correlate with differences in the patterns of decussation and central connectivity of the retinofugal axons. The ganglion cells with the largest somata, the alpha cells, form a discrete morphological and physiological cell type (Boycott and Wässle, 1974; Cleland et al., 1975; Wässle et al., 1975, 1981b). Their axons branch to project to several nuclei in the thalamus and brainstem (Kelly and Gilbert, 1975; Bowling and Michael, 1980; Illing and Wässle, 1981). Ganglion cells with small or medium-sized somata can be subdivided further in terms of other parameters. Most medium-sized ganglion cells represent a second distinct morphological class, the beta cell (Boycott and Wässle, 1974), and several lines of evidence suggest that the beta cell also represents a uniform physiological cell type with characteristic central projections (Rodieck, 1979; Wässle et al., 1981a; Saito, 1983). Other cells with medium-sized somata, however, differ from beta cells in their dendritic morphology and central connectivity (Leventhal et al., 1980; Leventhal, 1982). The smallest ganglion cells represent a heterogeneous group, for which the exact relationships between morphology and physiology are still only poorly understood.

These several ganglion cell classes, diverse in their form, function, and connectivity, differentiate from the initially uniform neuroepithelium of the optic cup. Following their last cell division, ganglion cell neuroblasts migrate away from the ventricular lumen and begin cytodifferentiation (Ramón y Cajal, 1929; Hinds and Hinds, 1974). The sequence in which ganglion cells undergo their final DNA replication, which can be determined using $\left[{ }^{3} \mathrm{H}\right]$ thymidine auloradiography, gives important information about the schedule of ganglion cell development.

Several $\left[{ }^{3} \mathrm{H}\right]$ thymidine studies in nonmammalian vertebrates have confirmed earlier histological studies (Mall, 1893; Glücksmann, 1940; Lyall, 1957; Johns and Easter, 1977) in showing that the retina grows primarily by the addition of new cells as rings to the retinal periphery (Hollyfield, 1968, 1972; Straznicky and Gaze, 1971; Jacobson, 1976; Johns, 1977). Studies on mammals have been more limited. Sidman (1961) showed that, in the mouse, large and small ganglion cells tend to be produced at different times, and that ganglion cells tend to be added in a central to peripheral sequence.

In the cat, the three ganglion cell size classes have distinct temporal patterns of production: medium-sized ganglion cells are 
produced before large ganglion cells, whereas the smallest ganglion cells are added throughout the period of ganglion cell generation (Polley et al., 1981; Walsh et al., 1982, 1983; Kliot and Shatz, 1982). This study was designed to determine to what extent these temporally distinct, central-peripheral waves of neurogenesis share a similar topography, and how this topographic pattern of ganglion cell production in the cat compares with the pattern of ganglion cell production seen in other vertebrates.

\section{Materials and Methods}

Tritiated thymidine injection. Tritiated thymidine was injected into the allantoic sac of 24 fetal cats of known age, between the 21 st and 36 th day of gestation (E21 to E36), according to a method described previously (Hickey et al., 1983). The fetuses developed normally and were killed by perfusion with $10 \%$ formal saline between 56 and 250 days after birth, by which time the three major ganglion cell size classes can be differentiated (Tucker, 1978). Despite strict control over the breeding conditions, some variability existed between labeling patterns of animals given injections at the same nominal age; thus, each gestational age carries an uncertainty of up to $36 \mathrm{hr}$. Our figures illustrate the general patterns of retinal development which emerged from our data.

Preparation of the retina. Some retinae were sectioned in the standard radial plane, but in order to allow analysis of the pattern of radioactive label in terms of retinal landmarks, a new embedding method was used (Polley and Walsh, 1984). The retinae were embedded in glycol methacrylate resin (a soft plastic) so that large regions of the retina could be sectioned en face, in a plane parallel to the retinal layers. These sections were cut at $5 \mu \mathrm{m}$, collected, and mounted on acid-cleaned, gel-coated glass slides. They were then processed for autoradiography using Kodak NTB-2 emulsion and standard dipping techniques (Rogers, 1979). After exposure in the dark for 10 days to 2 weeks, the autoradiographs were developed in D-19 and fixed in Rapid Fix, and the sections were counterstained with cresyl violet.

Analysis of autoradiographs. Histograms were used previously (Polley et al., 1981; Walsh et al., 1982, 1983) to illustrate the relationship of soma diameter to time of cell production. However, to show the overall topography of cell production, we found histograms unsatisfactory and, instead, reconstructed en face plots from 10 to 15 alternate, $5-\mu \mathrm{m}$ sections, to produce a complete view of the ganglion cell layer for a large part (although never all) of the retina.

The area centralis was located by drawing the region of highest cell density in 5 to 10 serial sections at $\times 50$ to $\times 100$, using a camera lucida. Superimposition of these drawings produced a single plot showing all alpha cells and blood vessels near the area centralis (Fig. 4), and the area centralis was taken as the region of highest alpha cell density which was also free of blood vessels.

Next, every second section through the ganglion cell layer was drawn at $\times 33$ to $\times 37$, and the sections were searched systematically with a $\times 100$ oil immersion objective. Each "heavily labeled" (defined below) ganglion cell with a nucleolus in the plane of section was plotted on the drawing, and the cell's soma diameter, nuclear diameter (average of largest and least diameters), and grain count were recorded. No correction was made for linear shrinkage (about 15\%, when retinae were measured before and after embed ding). The criteria for identifying ganglion cells were adapted from Stone (1978) and Hughes (1981). Cells which had a pale-staining nucleus with a single, distinct nucleolus in the plane of section, as well as well defined Niss bodies in the cytoplasm, were interpreted as ganglion cells (Fig. 1). When a heavily labeled nucleus contained a basophilic fold, a cytological feature said to characterize displaced amacrine cells in the ganglion cell layer (Hughes and Wieniawa-Narkiewicz, 1980), it was noted on the drawing. These cells were rarely heavily labeled in any of the plots shown.

Sidman (1970) has noted a purely geometrical tendency for larger nuclei to appear more lightly labeled than smaller nuclei. We calculated a correction for this tendency (corrected grain count $=$ nuclear diameter $\times$ grain count) and found that, for a range of nuclear sizes (4 to $11 \mu \mathrm{m})$ and section thicknesses ( 2 to $5 \mu \mathrm{m}$ ), this correction either compensated appropriately or overcompensated somewhat for this sampling difference, assuming the nuclei are (1) spherical, (2) flattened (1:2 or 1:3) in the plane of section, or (3) flattened (2:1 or $3: 1)$ normal to the plane of section. In practice, this correction made no qualitative changes in any of the plots.

Heavily labeled ganglion cells were defined as having corrected grain counts greater than half the maximum corrected grain count in the section. The maximum corrected grain count was defined as the average of the three highest counts in the section, and varied less than $15 \%$ through a series of sections. Since alpha cells comprise less than $5 \%$ of the total number of

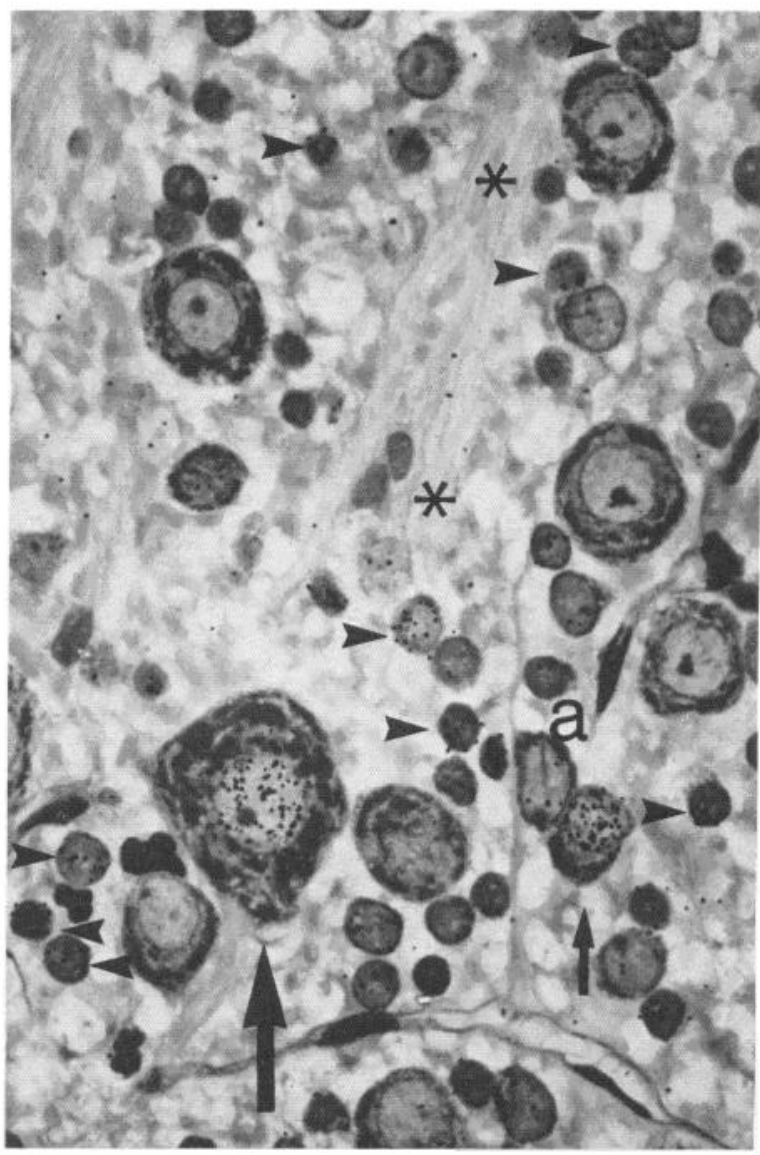

Figure 1. Photomicrograph of an en face section through the retinal ganglion cell layer of a cat exposed to $\left[{ }^{3} \mathrm{H}\right]$ thymidine on E31 and killed 65 days after birth. This field, in temporal retina near the horizontal meridian, shows a heavily labeled large ganglion cell and a heavily labeled small ganglion cell (arrows), according to the criteria of Stone (1978) and Hughes (1981); in contrast, several other ganglion cells of intermediate size are unlabeled, suggesting that they were postmitotic at the time of the $\left[{ }^{3} \mathrm{H}\right]$ thymidine injection. The nucleolus of the heavily labeled small ganglion cell was not included in the plane of this section. The nucleus of another cell showing lighter label (a) also contains a basophilic nuclear fold, which seems to characterize displaced amacrine cells (Hughes and Wieniawa-Narkiewicz, 1980). Several other labeled cells (arrowheads) are probably non-neuronal. Note also the staining of the longitudinally cut retinofugal fibers in the retinal nerve fiber layer (asterisks). Cresyl violet stain. Magnification $\times 720$.

ganglion cells, in order to obtain useful sample sizes, heavily labeled alpha cells were defined as having corrected grain counts greater than one-third the maximum. This did not substantially increase the extent of retina covered by heavily labeled alpha cells in any of the plots.

In the plots, ganglion cells were divided into four groups according to soma size: (1) alpha cells, which were identified by inspection (or, in a few dubious cases, by making cell size histograms), (2) non-alpha cells larger than $16 \mu \mathrm{m}$, (3) ganglion cells 12 to $16 \mu \mathrm{m}$ in diameter, and (4) ganglion cells less than $12 \mu \mathrm{m}$ in diameter (see Fig. 2). In 17 histograms prepared from five different retinae, sampling all four retinal quadrants and eccentricities ranging from the area centralis to peripheral temporal retina (Polley et al., 1981; Walsh et al., 1982, 1983; unpublished histograms), all ganglion cells larger than $16 \mu \mathrm{m}$ (excepting alpha cells) fell exclusively in the medium-sized cell mode, and all ganglion cells less than $12 \mu \mathrm{m}$ were limited to the small cell mode. Thus, the former serves as a sample of medium-sized cells and the latter serves as a sample of small cells. The $12-$ to $16-\mu \mathrm{m}$ category has a heterogeneous composition which changes in different retinal regions (see Fig. 2). The justification for this classification is discussed in more detail below (see "Grain counting and sampling of ganglion cell types," under "Discussion"). In the area centralis, where separate small and medium-sized cell modes cannot be distinguished, such a simple analysis is unreliable.

\section{Results}

Production of medium-sized ganglion cells. Most medium-sized ganglion cells are formed as a broad wave which begins superiorly 
a NEAR AREA CENTRALIS

b $5 \mathrm{~mm}$ TEMPORAL c $7 \mathrm{~mm}$ TEMPORAL

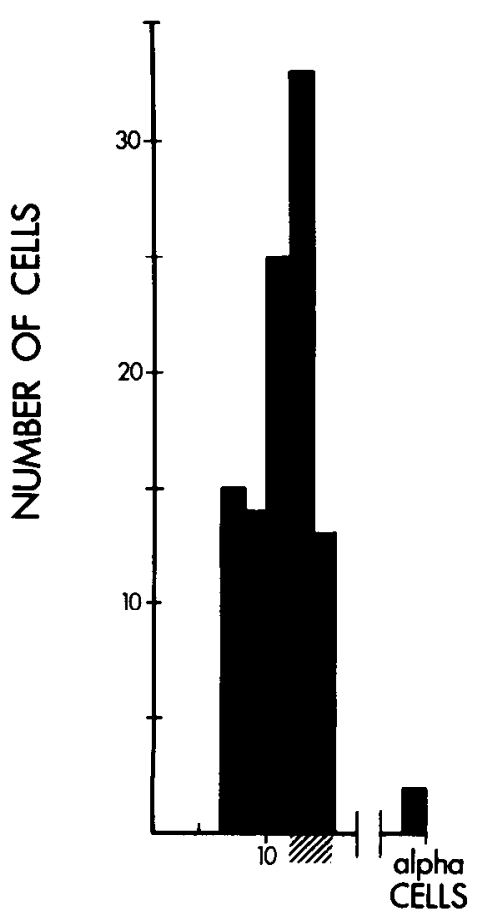

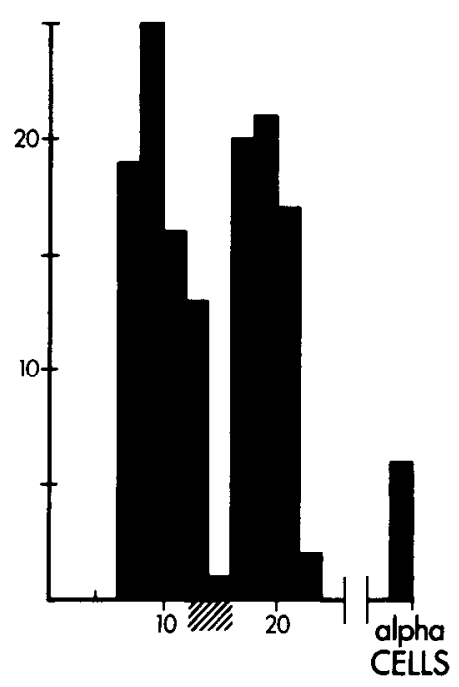

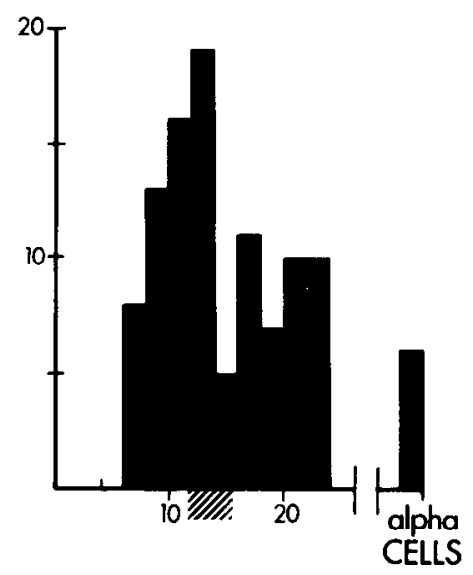

\section{SOMA DIAMETER $(\mu \mathrm{m})$}

Figure 2. Histograms showing cell size distribution in the retina of a cat killed 65 days after birth, to illustrate the subdivision of cells by size used in the plots. $a$ is taken from very near the area centralis, $b$ shows a region $5 \mathrm{~mm}$ temporal to the area centralis, and $c$ shows a region in the far temporal periphery. The largest cells, or alpha cells, are easily recognizable and make up less than $5 \%$ of the total number of cells. Outside of the area centralis, the remaining cells have a bimodal size distribution, with small and medium-sized modes. Note that cells greater than $16 \mu \mathrm{m}$ (excepting alpha cells) always fall in the medium-sized mode, and cells less than $12 \mu \mathrm{m}$ always fall in the small cell mode ( $b$ and $c$ ), and this is true in the other retinal quadrants as well (histograms not shown). Cells 12 to $16 \mu \mathrm{m}$ in diameter include portions of both the small and medium-sized cell modes. In nasal retina, where cells are in general smaller than in temporal retina, this 12- to 16- $\mu \mathrm{m}$ size group included a larger proportion of cells in the medium-sized mode. Thus, the 12- to 16- $\mu \mathrm{m}$ size group is heterogeneous, and its composition varies with retinal location; therefore, cells in this size range were not studied in detail. In the area centralis (a), separate small and medium-sized modes cannot be demonstrated. See the text for further discussion.

and nasally to the area centralis and spreads to include inferior nasal retina and inferior temporal retina in rough sequence. The earliest successful injections, at E21, produced a few heavily labeled medium-sized cells (as well as heavily labeled small cells-see below), but many cells were more lightly labeled. Heavily labeled cells were scattered but were most common over a broad central region above the optic disc and nasal to the area centralis. Heavily labeled cells were especially common immediately superior and nasal to the area centralis, and the number of heavily labeled cells dropped markedly from the nasal to the temporal side of the area centralis.

injections at E22 to E24 produced many more heavily labeled medium-sized ganglion cells in a larger central retinal region, with more labeled cells in temporal retina. Figure $3 a$ illustrates the distribution of heavily labeled medium-sized cells (see "Materials and Methods" for definition) in the central retina of a cat given $\left[{ }^{3} \mathrm{H}\right]$ thymidine on E23. The rest of the retina was studied, although not plotted, in other animals. Heavily labeled medium-sized ganglion cells were most common in superior nasal retina and the immediately adjoining portion of superior temporal retina. They were also common in inferior nasal retina, but far fewer heavily labeled cells were present in inferior temporal retina. A sharp decussation line separates medium-sized cells in temporal retina, all of which have uncrossed axons, from medium-sized cells in nasal retina, all of which have crossed axons (Stone, 1966; Cooper and Pettigrew, 1979; lling and Wässle, 1981). Thus, whereas injections at E21 to E23 produced heavily labeled cells in superior retina with both crossed and un- crossed axons, heavily labeled cells in inferior retina formed an almost pure-crossed population.

Later injections (E25 to E28) showed heavily labeled mediumsized cells over virtually the entire retinal surface, but the distribution of heavily labeled medium-sized cells was not uniform. Injections at E25 produced many heavily labeled medium-sized cells everywhere except in temporal retina near and below the horizontal meridian. Later injections (E26 to E28) produced increasing numbers of heavily labeled medium-sized cells in inferior temporal retina, but decreasing numbers of labeled medium-sized cells in superior nasal retina and the immediately adjoining portion of superior temporal retina. This is illustrated in Figure $3 b$, which is a plot of heavily labeled mediumsized cells after $\left[{ }^{3} \mathrm{H}\right]$ thymidine injection at $\mathrm{E} 27$. This figure shows a distribution of labeled medium-sized cells essentially complementary to that seen after injection at E23 (cf. Fig. 3a).

Injections at E29 showed no labeled medium-sized cells in nasal retina except in the periphery, whereas in temporal retina heavily labeled medium-sized cells were common near and below the horizontal meridian (Fig. $3 c$ ). Whereas in temporal retina labeled medium-sized cells were found within $1 \mathrm{~mm}$ of the area centralis, in nasal retina the nearest heavily labeled medium-sized cell was at least $6 \mathrm{~mm}$ away. Heavily labeled medium-sized cells in temporal retina were most common inferior to the retinal raphé, the region that separates ganglion cells whose axons course superior to the area centralis from those whose axons loop inferior to the area centralis to reach the optic nerve head. This is illustrated in Figure 
a.

E23

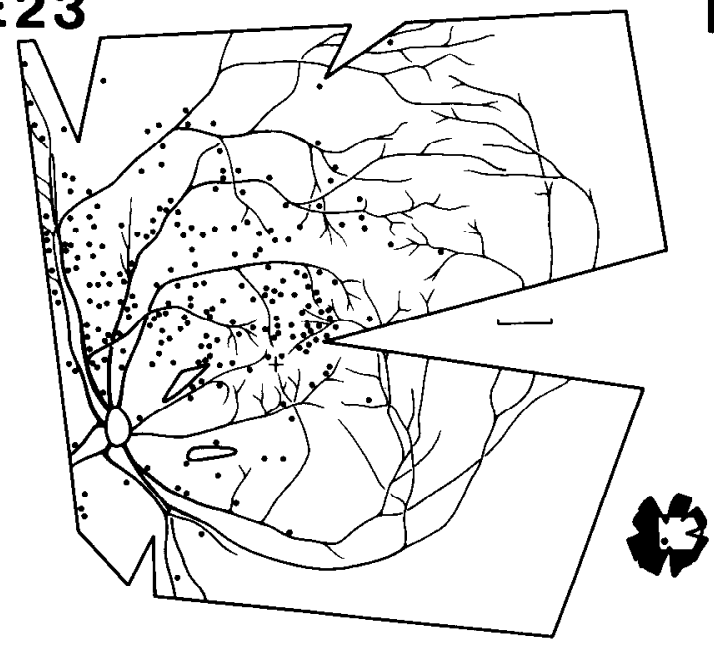

b.
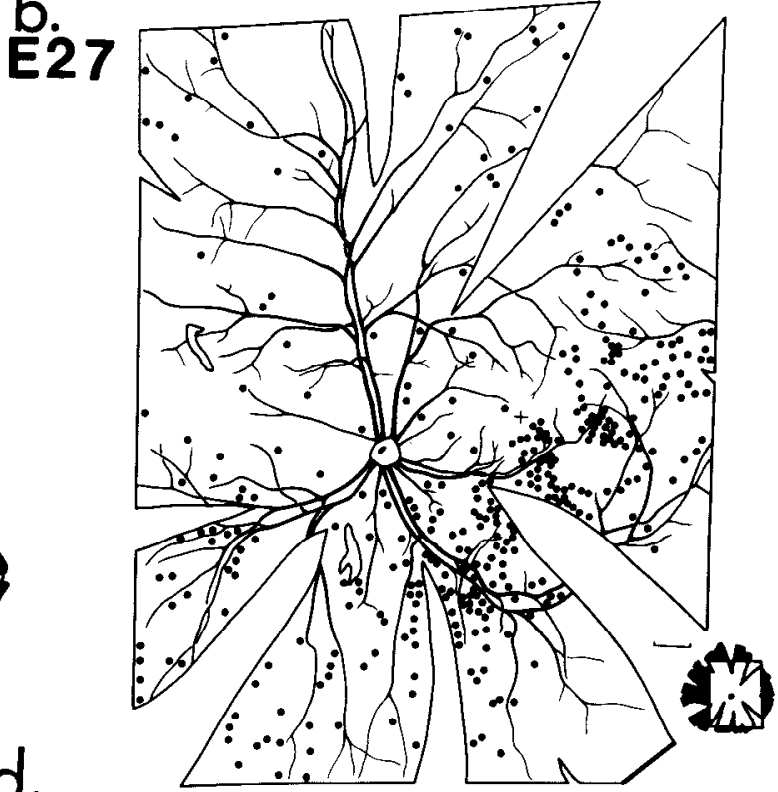

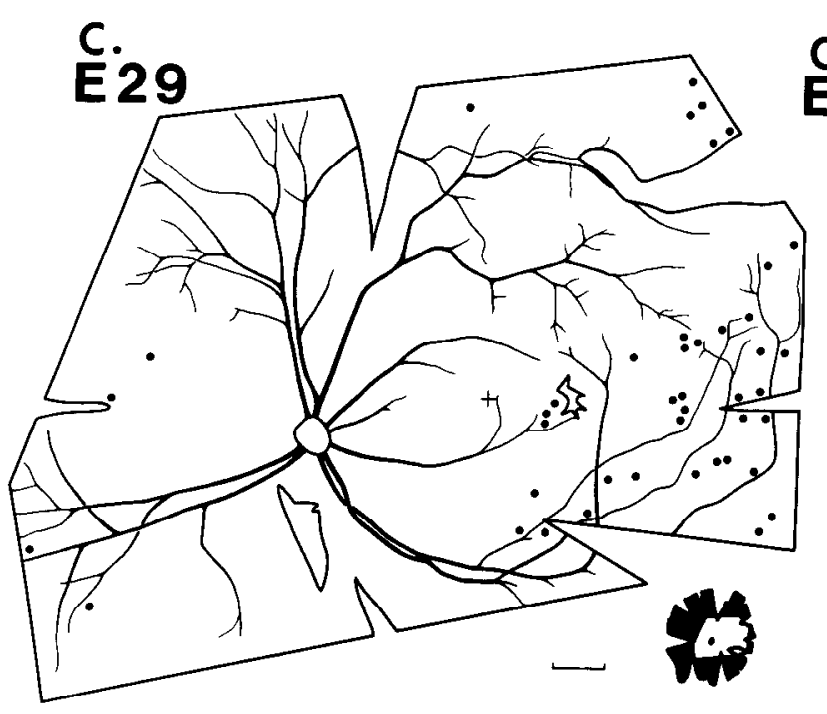

d.

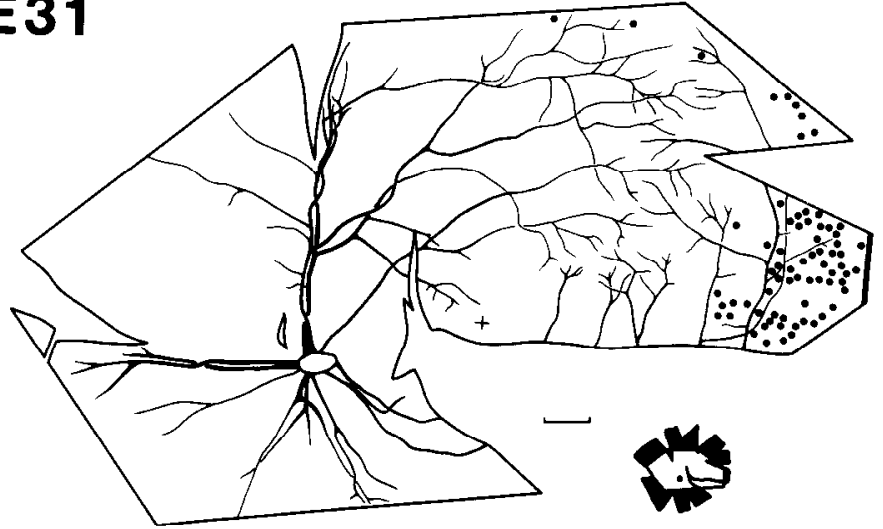

Figure 3. Plots of heavily labeled medium-sized ganglion cells (non-alpha cells larger than $16 \mu \mathrm{m}$ in diameter) in the retinae of animals given [ ${ }^{3} \mathrm{H}$ ]thymidine on E23, E27, E29, and E31. a shows the retina of an animal given $\left[{ }^{3} \mathrm{H}\right]$ thymidine on E23 and killed 60 days after birth, and shows that heavily labeled medium-sized cells lie mainly in superior nasal retina and the adjoining zone of superior temporal retina near the vertical meridian. Fewer heavily labeled cells are seen in inferior nasal retina, and very few are seen in inferior temporal retina. $b$ shows the retina of an animal given [ $\left.{ }^{3} \mathrm{H}\right]$ thymidine on E27 and killed 196 days after birth, and shows heavily labeled medium-sized cells over the entire retina, although they are more common in inferior nasal retina and in temporal retina inferior to the raphé. The raphé is shown by the region of overlap of the blood supply to superior temporal retina from superior nasal retina and from inferior temporal retina (Murakami et al., 1982). Heavily labeled medium-sized cells in this retina are much less common in superior nasal retina and the adjacent portion of superior temporal retina near the vertical meridian, producing a labeling pattern complementary to that seen in $a$. $c$ shows the retina of an animal given $\left[{ }^{3} \mathrm{H}\right]$ thymidine in E29 and killed 206 days after birth, and shows heavily labeled medium-sized cells mainly in temporal retina inferior to the retinal raphé, with heavily labeled medium-sized cells in nasal retina present only in the periphery. $d$ shows the retina of an animal given [ $\left.{ }^{3} \mathrm{H}\right]$ thymidine on E31 and killed 65 days after birth and shows heavily labeled medium-sized cells confined to the peripheral retina. Although the periphery of temporal retina only is shown in this drawing, the far periphery of the entire retina showed a few heavily labeled medium-sized ganglion cells in other animals given [ ${ }^{3} \mathrm{H}$ ] thymidine at this age. In each drawing, the outlines represent the limits of the retinal region analyzed, and this region is indicated in the inset. The area centralis is shown as a cross, with the orientation of the axes of the cross approximating that of the horizontal and vertical meridians (Bishop et al., 1962; Cooper and Pettigrew, 1979). In all drawings, nasal is to the left, temporal is to the right, and superior retina is above. The optic disc, which lies in nasal retina, is shown by an irregular circle from which the major blood vesscls radiate. Cuts and tears made in the retina during processing are aiso shown, and the ora serrata, where included in the drawing, is shown by a bold line. Scale bars $=1 \mathrm{~mm}$.

$3 c$, where the raphe is represented by the region of overlap of two groups of blood vessels supplying superior temporal retina, one group approaching nasally, the other, inferiorly (Murakami et al., 1982).

The absence of label among medium-sized ganglion cells near the optic disc following injection at E29 is confirmed by an analysis of label among cells less than $16 \mu \mathrm{m}$ in diameter (see Fig. 6a). The distribution of heavily labeled cells 12 to $16 \mu \mathrm{m}$ in diameter (representing a mixture of small and medium-șized cells) was essentially identical to that of cells larger than $16 \mu \mathrm{m}$. The only cells labeled in nasal retina near the optic disc had somata less than $12 \mu \mathrm{m}$ in diameter, and in histograms (some taken from the retina contralateral to the one shown here), cells in this size range never included medium-sized cells.

Very few medium-sized cells were labeled by injections atter E29. Following injections at E31, labeled medium-sized cells were mainly limited to the peripheral retina (see Fig. $3 d$ ). Although no cells larger than $16 \mu \mathrm{m}$ were labeled in central retina, some heavily labeled cells 
near the optic disc had somata up to $15.5 \mu \mathrm{m}$ in diameter (see Fig $6 b$ ). Some of these cells may represent a smaller group of mediumsized cells produced later, and separately, from the major wave of production of medium-sized ganglion cells. Whether these younger cells represent amacrine cells or a distinct morphological or physiological ganglion cell type is unknown. Another injection at E35 labeled very few medium-sized cells adjacent to the ora serrata, and no labeled medium-sized ganglion cells were seen after an injection at E36.

Production of large ganglion cells. The largest ganglion cells, or alpha cells, are produced as a second roughly spiral wave with the same topography as the wave which produces the majority of the medium-sized cells. Although shifted about 4 days relative to the medium-sized cell wave, the production of large cells overlaps the production of medium-sized cells extensively.

The oldest large cells are widely scattered and lie, in general, superior and nasal to the area centralis. Although six cats given $\left[{ }^{3} \mathrm{H}\right]$ thymidine before E25 showed no heavily labeled large cells, two cats given $\left[{ }^{3} \mathrm{H}\right]$ thymidine at E25 showed several heavily labeled large cells. They were all above the optic disc, and most were above the horizontal meridian (see Fig. 5a). Although scattered, they were especially common immediately superior and nasal to, and extending up to, the area centralis. Figure 4 illustrates their decidedly asymmetric distribution relative to the area centralis: heavily labeled large cells were common superior and nasal to the area centralis and spilled over somewhat across the retinal vertical meridian representation into superior temporal retina. Figure 4 also shows that there was no consistent tendency for nearest-neighbor large cells to have matching amounts of label, since most heavily labeled large cells had lightly labeled (or unlabeled) neighbors.

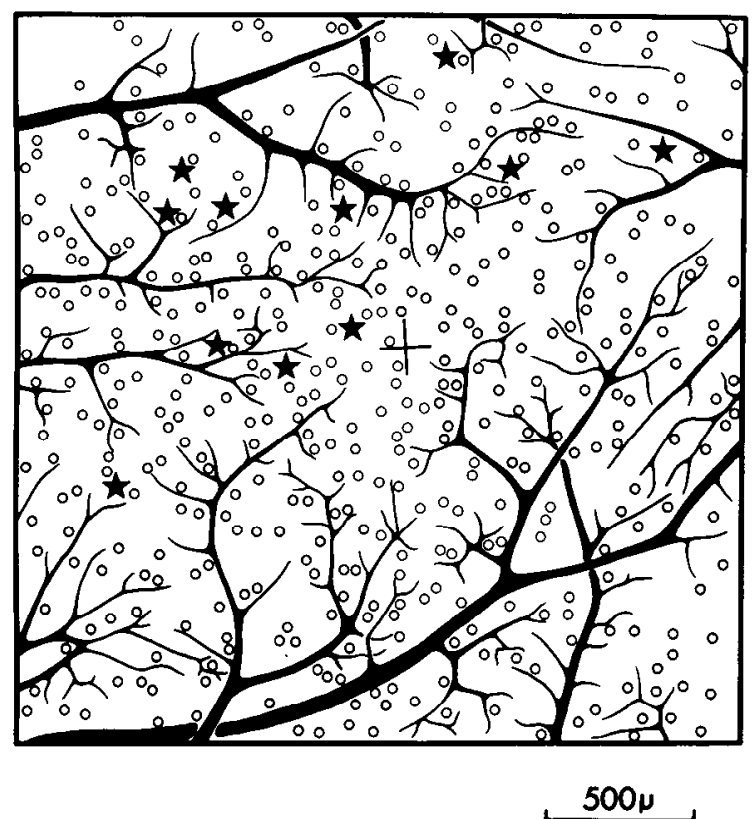

Figure 4. A plot showing alpha cells near the area centralis, from an animal given $\left[{ }^{3} \mathrm{H}\right]$ thymidine on $\mathrm{E} 25$ and killed 56 days after birth. The region shown in this figure is indicated by the dashed square outline in Figure 5a. Heavily labeled alpha cells are shown by stars, and more lightly labeled (or unlabeled) alpha cells are indicated by open circles. This figure was prepared from serial 5- $\mu \mathrm{m}$ sections rather than alternate sections, as was the case in Figure $5 a$ and other figures, and this explains the higher density of heavily labeled alpha cells in this figure. Note that heavily labeled alpha cells lie superior and nasal to the area centralis and that they extend up to the zone of maximal cell density and up to the retinal raphé (defined by overlap of blood vessels), but no further. The overall density of alpha cells in this figure agrees with other published estimates (Wässle et al., 1975; Stone, 1978) within $20 \%$, confirming that alpha cells can be identified readily in these Nissl-stained sections.
Injections at later ages (E26 to E28) produced heavily labeled large cells over a wide retinal region including inferior nasal retina and more of temporal retina. Figure $5 b$ shows the retina of an animal given $\left[{ }^{3} \mathrm{H}\right]$ thymidine at E27 and shows that heavily labelcd large cells covered most of the area sampled. However, they were more common in superior nasal retina and the immediately adjoining region of superior temporal retina than they were in inferior nasal retina, and they were notably less common in inferior temporal retina. This distribution (Fig. 5b) resembles the distribution of heavily labeled medium-sized cells after injection at E23 (cf. Fig. 3a). Note that, with rare exceptions, all heavily labeled large cells in superior retina were nasal to the raphé

As heavily labeled large ganglion cells became more common in temporal retina after large injections (E28 to E29), they became less common in those retinal regions containing the oldest large cells. Figure $5 c$ shows a plot of heavily labeled large cells following an injection at E29. Heavily labeled large cells were again scattered over most of the area sampled. However, they were slightly more common in inferior nasal retina than in superior nasal retina and were increasingly more common in inferior temporal retina. Virtually all labeled large cells in superior retina were nasal to the raphé. The tendency for inferior nasal retina to contain more heavily labeled large cells than superior nasal retina was clearer in another animal, from a different litter, also given $\left[{ }^{3} \mathrm{H}\right]$ thymidine on E29 (not illustrated). We interpret this animal as having been slightly older at the time of injection than the animal shown in Figure $5 c$, suggesting that production of large cells ceases first in superior rasal retina.

Still later injections (E31) labeled no alpha cells near the optic disc. In an animal given $\left[{ }^{3} \mathrm{H}\right]$ thymidine on $\mathrm{E} 31$, no labeled large cells were present in the nasal retina except in the periphery (Fig. 5d). Heavily labeled large cells were mainly limited to retina near and below the horizontal meridian of the temporal retina (see Fig. $5 d$ ). Thus, the overall distribution of heavily labeled large cells after thymidine injection at E31 was similar to the distribution of heavily labeled medium-sized cells after injection at E29 (cf. Fig. 3c). Injections made later than E31 (E35 to E36) labeled very few alpha cells adjacent to the ora serrata.

Production of small ganglion cells. Small ganglion cells are produced gradually over the entire period of ganglion cell generation, extending at least from E21 to E36. After the earlier injections (E21 to E27), the distribution of heavily labeled small ganglion cells matched that of heavily labeled medium-sizcd cells. After injection at E21, heavily labeled small and medium-sized ganglion cells were plotted (although no soma size analysis was done). Labeled cells were more common in superior nasal retina than in inferior nasal retina, suggesting that the small cell wave may also begin in superior nasal retina. Following injections at later ages, medium-sized cell labeling expanded to cover more of the retina, and label among small cells also expanded, covering most of the retina following injections at E27.

After later injections (E28 to E29), label among small cells continued to cover the whole retina as label among medium-sized ganglion cells and, later, among large cells receded from central retina (Fig. $6 a)$. After an injection at E31, there is a hint that production of small cells may be nearing completion, as a region directly above the area centralis is devoid of labeled ganglion cells (Fig. 6b). A larger region of superior retina showed no labeled ganglion cells after injection at E35, although labeled small ganglion cells were identified near and below the horizontal meridian. Thus, the broad wave of production of small ganglion cells also seems to follow a spiral pattern at its beginning and end. However, because of the difficulty in distinguishing small ganglion cells from other cell types in the ganglion cell layer, we have not attempted to determine the age at which ganglion cell production ceases.

Relationship of ganglion cell production to the retinal raphé. In most of our material the raphe separates retinal regions with disparate labeling patterns. This is well illustrated by comparing labeling among large and medium-sized ganglion cells after $\left[{ }^{3} \mathrm{H}\right]$ thymidine 
a.

\section{E25}

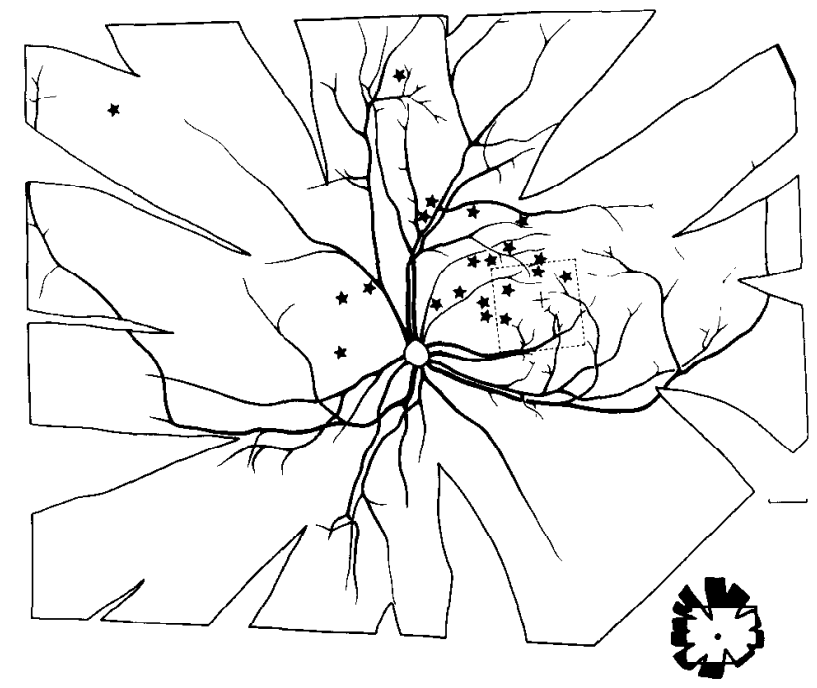

b.
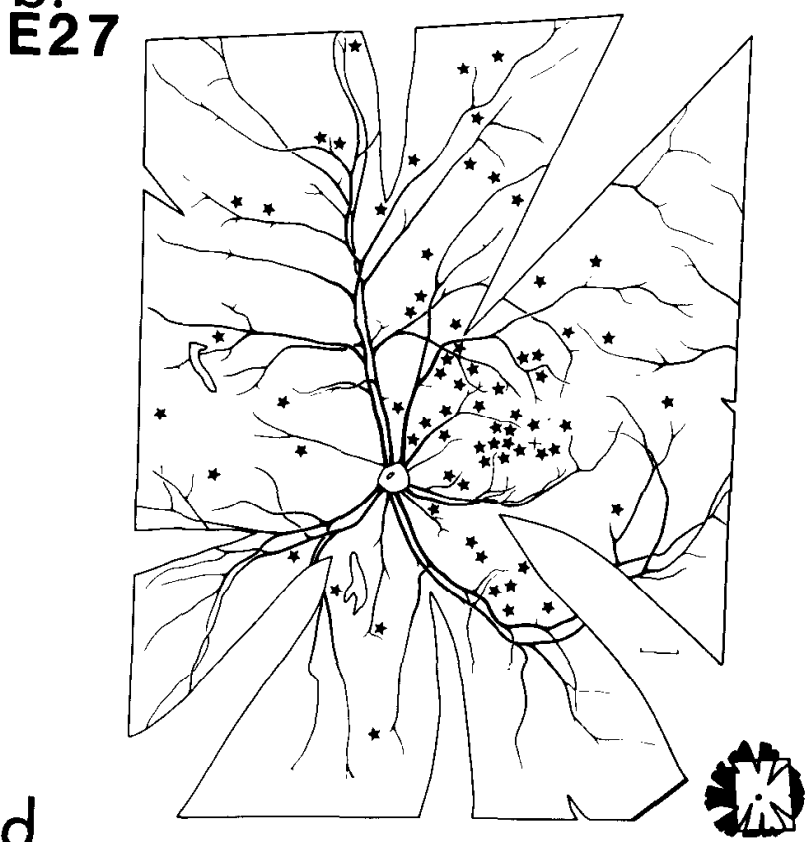
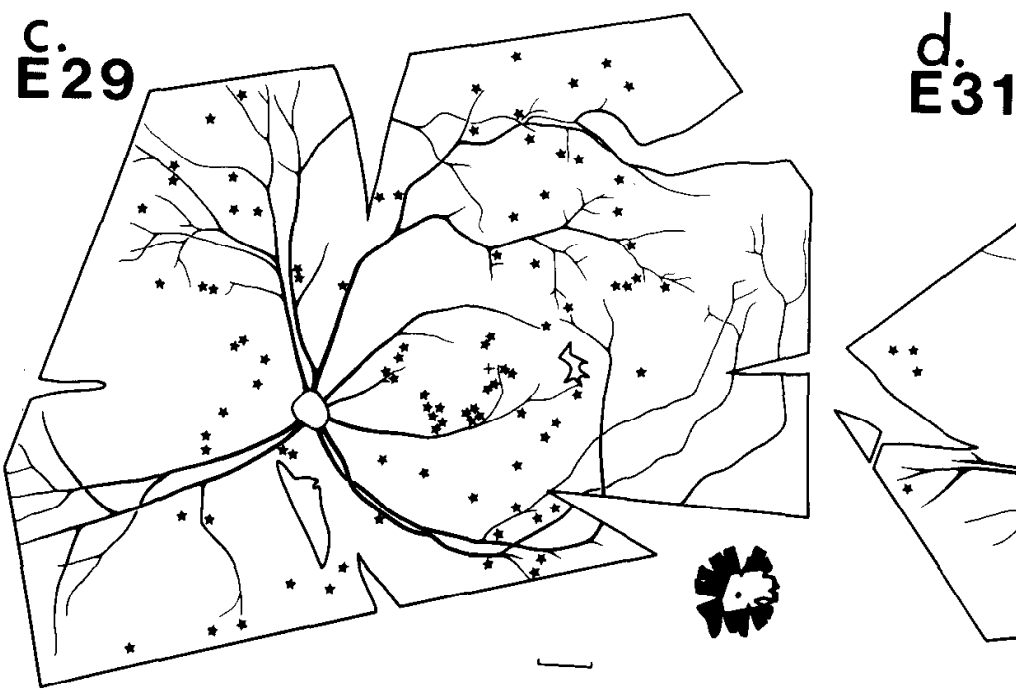

Figure 5. Plots of heavily labeled alpha cells in the retinae of cats given $\left[{ }^{3} \mathrm{H}\right]$ thymidine on E25, E27, E29, and E31. a shows the retina of an animal given $\left[{ }^{3} \mathrm{H}\right]$ thymidine on E25 and killed 56 days after birth, and shows heavily labeled alpha cells over a broad retinal region, but mainly in superior nasal retina. $b$ shows the retina of an animal given $\left[{ }^{3} \mathrm{H}\right]$ thymidine on E27 and killed 196 days after birth (prepared from the same retina shown in Fig. $3 b$ ), and shows heavily labeled alpha cells distributed over a very broad region of central retina. They are common in superior nasal retina and the adjacent portion of superior temporal retina (up to the retinal raphé), slightly less common in inferior nasal retina, and uncommon in temporal retina inferior to the raphé. $c$ shows the retina of an animal given $\left[{ }^{3} \mathrm{H}\right]$ thymidine on E29 and killed 206 days after birth (prepared from the same retina shown in Fig. $3 \mathrm{c}$ ), and again shows heavily labeled alpha cells over most of the retina, although in nasal retina they are slightly more common in inferior nasal than in superior nasal retina, and in temporal retina they are uncommon near and below the horizontal meridian. $d$ shows the retina of an animal given $\left[{ }^{3} \mathrm{H}\right]$ thymidine on E31 and killed 65 days after birth (the same retina shown in Fig. $3 d$ ), and shows heavily labeled alpha cells mainly in temporal retina, distributed in a region bounded superiorly and nasally by the retinal raphé. Inferior temporal retina, although not included in the block sectioned to make this plot, was sectioned and analyzed separately and contained many heavily labeled alpha cells. Conventions for all of these drawings are as in Figure 3 .

injection at E27 or E29 (cf. Figs. $3 b$ and $5 b, 3 c$ and $5 c$ ). In each case the raphé separated regions containing many labeled large cells (nasally) from regions containing many labeled medium-sized cells (temporally). The region where this boundary was clearest was nearer the area centralis after the earlier injection and farther peripheraily after the later injection. After injection at E25 the raphe again clearly separated regions containing heavily labeled large cells from regions containing no heavily labeled large cells at all, with this boundary clearest in the area centralis itself (see Figs. 4 and 5a). In contrast, much later injections (E31) labeled large cells only temporal to the raphe (Fig. 5d). Thus, for ganglion cells in any size class, cells nasal to the raphe are substantially older than cells temporal to it.

\section{Discussion}

In this study we describe the spatial pattern of production of the ganglion cells in the cat's retina. Cells in different size classes are produced as several overlapping, temporally distinct waves (Waish et al., 1983). Each wave follows the same distinctive topography, forming a rough spiral around the area centralis. This pattern of neurogenesis can be related to the development of the retina in general, to the partial decussation of the retinofugal axons, and to the organization of these axons in the brain. However, before discussing these issues, some technical points must be addressed.

Grain counting and sampling of ganglion cell types. Construction of en face plots required comparisons of grain counts within and 


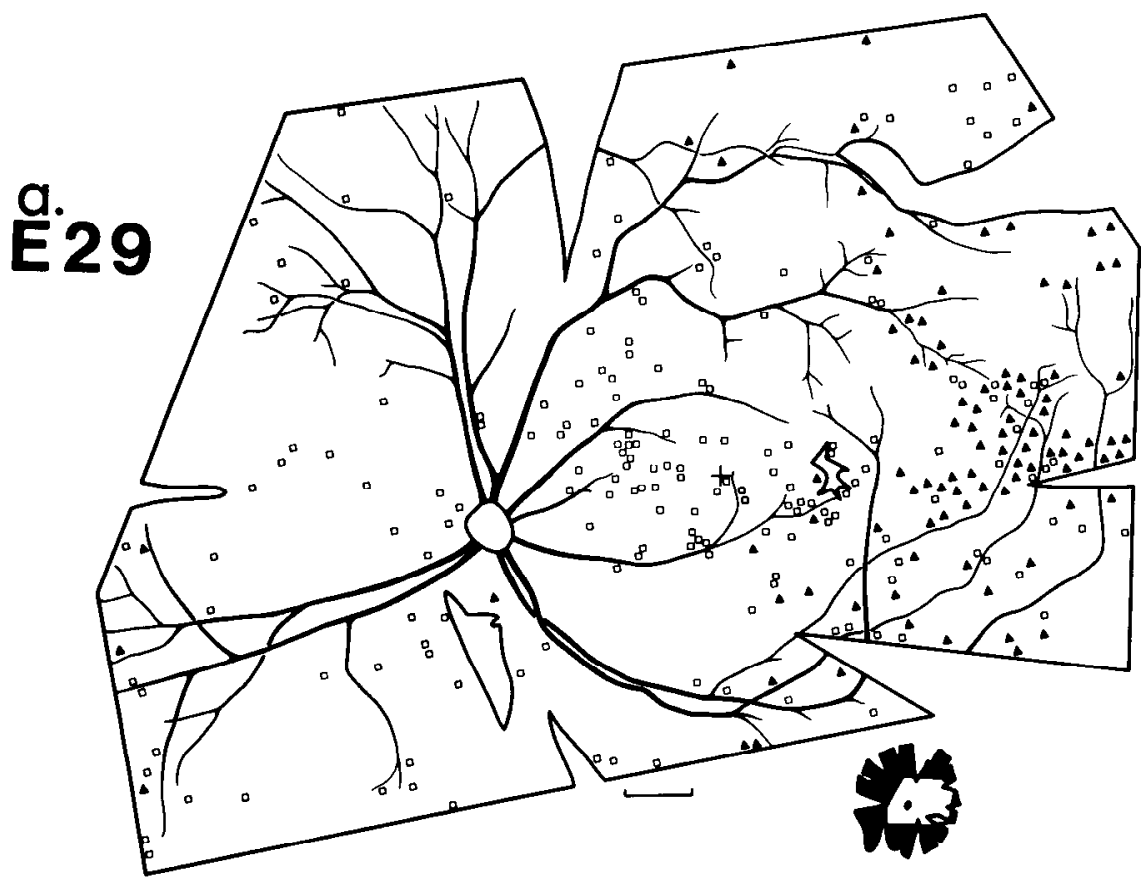

Figure 6. Plots of heavily labeled ganglion cells less than $16 \mu \mathrm{m}$ in diameter, from the retinae of animals given $\left[{ }^{3} \mathrm{H}\right]$ thymidine on E29 and E31. Injections at earlier ages produced patterns of label among cells less than $16 \mu \mathrm{m}$ that matched the pattern of label among nonalpha cells larger than $16 \mu \mathrm{m}$ in diameter (see Fig. 3, $a$ and $b$ ). a shows the retina of an animal given $\left[{ }^{3} \mathrm{H}\right]$ thymidine on $\mathrm{E} 29$ and killed 206 days after birth (cf. Figs. $3 c$ and $5 c$ ). Heavily labeled small ganglion cells less than $12 \mu \mathrm{m}$ in diameter, indicated by open squares, cover the entire retinal region samples. Ganglion cells 12 to 16 $\mu \mathrm{m}$ in diameter are indicated by solid triangles and represent a heterogenous population including both small and medium-sized ganglion cells. Since average ganglion cell size varies across the retina, the proportion of small or medium-sized cells in the $12-$ to $16-\mu \mathrm{m}$ size range varies with retinal position. The distribution of heavily labeled cells 12 to $16 \mu \mathrm{m}$ in diameter is similar in this retina to the distribution of medium-sized cells larger than $16 \mu \mathrm{m}$ in diameter (cf. Fig. 3c): they are limited to peripheral areas of nasal retina, whereas they are common in temporal retina near, and inferior to, the horizontal meridian. $b$ shows the retina of an animal given $\left[{ }^{3} \mathrm{H}\right]$ thymidine on E31 and killed 65 days after birth (the same retina shown in Figs. $3 d$ and $5 d$ ), and shows very few labeled cells superior to the area centralis, suggesting that ganglion cell production here may be nearing completion. Heavily labeled small cells less than $12 \mu \mathrm{m}$ in diameter (open squares) are distributed over most of the retina. Solid triangles represent cells 12 to $16 \mu \mathrm{m}$, including both small and medium-sized cells. Some of the cells 12 to $16 \mu \mathrm{m}$ in diameter which are labeled in central retina may represent a population of relatively young medium-sized cells which are not labeled after injections at slightly eartier ages (cf. Fig. 6a). See the text for further explanation. Conventions for both drawings are as in Figure 3.

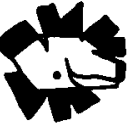

between sections, raising the possibility that variations in emulsion thickness, section thickness, or other parameters of the autoradiographic process may have introduced spurious regional differences in labeling. However, maximum grain counts varied less than 10 to $15 \%$ between sections or between slides in a series, and all of the major differences in labeling patterns were both recognizable in a single section and consistent between sections.

The sampling procedure we have used needs some discussion. Since large (alpha) cells are easily recognizable in Nissl preparations, all large cells present in a series of alternate $5-\mu \mathrm{m}$ sections were sampled. As alpha cells make up less than $5 \%$ of the total number of ganglion cells, they were deliberately oversampled by interpreting large cells with corrected grain counts greater than one-third the maximum (rather than one-half) as heavily labeled, although this did not significantly enlarge the region of retina covered by labeled large ganglion cells in any of the plots. Also, all of the plots shown (for all ganglion cell size classes) are derived from initial samples which included $1 \frac{1}{2}$ to 2 times as many cells as are illustrated, the remaining cells being eliminated after the maximum grain count for each section had been definitively determined. The labeling patterns seen in this larger sample were always consistent with those illustrated.

The medium-sized and small ganglion cells are more numerous than the large cells, but sampling them presents two problems: (1) there is no obvious boundary or morphological distinction between small and medium-sized ganglion cells, and (2) the size boundary defined by others (Stone, 1978; Hughes, 1981) shifts with retinal locus. Since histograms show that cells (excluding alpha cells) with somata larger than $16 \mu \mathrm{m}$ always represent medium-sized cells in our material (see Fig. 2), we analyzed medium-sized cells by plotting labeled cells in this size range. This sample thus includes the larger medium-sized ganglion cells, and the proportion of the smaller cells within the medium-sized mode which is excluded from this sample varies with retinal eccentricity. In general, the smaller and larger cells within the medium-sized mode showed the same topography of production, as the distribution of label among cells 12 to $16 \mu \mathrm{m}$ in diameter usually matched closely the distribution of label among 
medium-sized cells larger than $16 \mu \mathrm{m}$ (cf. Figs. $3 \mathrm{c}$ and $6 \mathrm{a}$ ). An important exception is represented by the cells, many of them up to $15.5 \mu \mathrm{m}$ in diameter, labeled near the optic disc following $\left[{ }^{3} \mathrm{H}\right]$ thymidine injections at E31 (Fig. 6b). Some of these labeled cells probably fall in the medium-sized mode. The identity of these cells is uncertain, but we tentatively suggest that, whereas beta cells are formed in the main wave of medium-sized cell production, this younger group of small and medium-sized cells includes the epsilon cells (Leventhal et al., 1980; Leventhal, 1982).

The suggestion that beta cells are older than epsilon cells is supported by experiments in the ferret reported elsewhere (C. Walsh and R. W. Guillery, unpublished results), in which the older retinotugal axons and terminals were selectively labeled by an intravitreal injection of ${ }^{3} \mathrm{H}$-amino acids given on E27 to E29, during the period of ganglion cell production. When these ferrets (a close relative of the cat with similar visual system organization and development) were killed 3 weeks postnatally (by which time the retinofugal projection is, in general, adult-like), label among the older retinofugal terminals was heavier in the A layers of the lateral geniculate nucleus, the major target of beta cell axons, and lighter in the $C$ layers, the medial intralaminar nucleus, and the geniculate wing, the known targets of epsilon cell axons. Injections into older animals followed by a similar survival time produced more uniform label in all of these targets. This suggestion that beta cells are older than epsilon cells can only be evaluated by combining $\left[{ }^{3} \mathrm{H}\right]$ thymidine autoradiography with techniques that reveal dendritic morphology or central connections $(E$. H. Polley, work in progress).

Small ganglion cells were sampled by plotting labeled cells less than $12 \mu \mathrm{m}$ in diameter, since cells in this size range were restricted to the small cell mode in our histograms (Walsh et al., 1982, 1983; see Fig. 2; other histograms are unpublished). Small cells are produced throughout the period of ganglion cell addition, and this broad wave of production may represent several concatenated waves of addition of the several morphological subtypes of small ganglion cell. This, however, remains unproven. There may also be differences in age between small cells in temporal retina which have crossed or uncrossed axons, since we have referred elsewhere (Walsh et al., 1983), to indirect evidence that suggests that the small cells in temporal retina with crossed axons are among the youngest cells in temporal retina. Again, resolution of these questions requires combination of $\left[{ }^{3} \mathrm{H}\right]$ thymidine autoradiography with techniques for revealing dendritic morphology and central connectivity.

Comparison with earlier studies of ganglion cell production. Our results illustrate that ganglion cell addition in the cat's retina follows quite different rules from those seen in nonmammalian vertebrates. In frogs and fish, ganglion cell addition continues throughout life by the addition of rings of new cells to the retinal periphery (Hollyfield, 1968, 1972; Straznicky and Gaze, 1971; Jacobson, 1976; Johns, 1977), resulting in a sequence of ganglion cell addition which represents a single retinal map. In the cat's retina, however, ganglion cell production (1) is temporally limited, being mainly completed during a 2-week period, (2) is resolvable into several waves of production of distinct cell size classes, and (3) occurs over a very rough central-peripheral gradient not in accord with the precise maps formed centrally by the eye on the brain such that, at many ages (e.g., E26 to E31), new ganglion cells-even within one size classare apparently added simultaneously over large parts of the retinal surface.

Ganglion cell production in the cat may be compared more truittully to the very earliest stages of ganglion cell addition in nonmammalian vertebrates, before the distinctive annular addition becomes established. in these earliest stages, ganglion cell addition shows a marked dorsal-ventral asymmetry in all species examined, with the oldest ganglion cells lying superior to, and in general to one side of, the optic disc, comparable to our results in the cat (von Szilly, 1912; Mann, 1928, 1964; Goldberg and Coulombre, 1972; Kahn, 1973; Grant and Rubin, 1980; Sharma and Ungar, 1980). The addition of ganglion cells as annuli could then be viewed as a specialization of frogs and fish, perhaps allowing them to add new cells to an already functioning retina (S. Easter, personal communication), but should not be viewed as a general paradigm of vertebrate retinal growth (see also Sidman, 1961; Lund and Bunt, 1976; Johns et al., 1979). It would be interesting to see whether an analogous roughly spiral pattern (perhaps defined with respect to the optic disc) obtains at the earliest stages of ganglion cell production in frogs and fish. Such a pattern results in a rough but definable temporal sequence in production of cells in the different retinal quadrants and produces spirals with different orientation (i.e., clockwise or counterclockwise) in the two eyes, and therefore could have important consequences for the development of maps in the brain.

Retinal growth and maturation. Overproduction of ganglion cells, followed by cell death, has been documented in several mammalian species (Sengelaub and Finlay, 1981; Cunningham et al., 1982; Jeffery and Perry, 1982; $\mathrm{Ng}$ and Stone, 1982; Rakic and Riley, 1983), and this cell death may be nonuniform across the retinal surface (Stone et al., 1982; Sengelaub et al., 1983). Some ganglion cell precursors may be secondarily coverted into amacrine cells (Hinds and Hinds, 1978, 1983), and ganglion cell distribution and density are also affected by the nonuniform growth of the retina (Mastronarde et al., 1984). However, tangentially migrating neurons, which have a characteristic morphology and orientation (Ramón y Cajal, 1929) have never been observed in the developing retinal ganglion cell layer, and this suggests that the topographic pattern of label described here accurately represents the pattern of production of those ganglion cell neuroblasts which survive in the adult.

The disposition of the several roughly spiral waves of ganglion cell production with respect to the area centralis makes this point a definable landmark even from the earliest stages of neurogenesis. The area centralis is not the sole locus of the oldest ganglion cells (cf. Kliot and Shatz, 1982) and seems not to show any special burst of neurogenetic activity. Instead, the area centralis adds its large complement of ganglion cells at a leisurely pace but forms a node. or fulcrum, about which ganglion cell production in the retinal quadrants pivots. This position as a pivot distinguishes the area centralis, regardless of whether the early distribution of ganglion cells is uniform (Stone et al., 1982; Rapaport and Stone, 1984) or nonuniform (Lia et al., 1983), and, thus, those factors responsible for the formation of the area centralis can be presumed to be operative as the first ganglion cells are formed.

Relationship of ganglion cell production to retinofugal fiber organization. Our results show that, just as the timing of production of ganglion cells alone cannot account for the precise maps made by the eye on the brain (Walsh et al., 1983), it also seems insufficient alone to produce the partial decussation which characterizes the cat's retinofugal projection. Whereas nasal-temporal differences in the production of medium-sized and large ganglion cells are sometimes striking in inferior retina (see Fig. $3 a$ and $c$ ), this is not true in superior retina, where a portion of superior temporal retina develops along with superior nasal retina, and where nasal-temporal differences in the timing of ganglion cell production near the vertical meridian are slight or absent. We have described previously an intriguing indirect relationship between ganglion cell birthdates and axonal decussation patterns, in which the line of decussation is less sharp and progressively shifted into temporal retina for younger ganglion cells (Walsh et al., 1983).

Although the cat's retina adds ganglion cells in a pattern very different from that seen in nonmammalian vertebrates, in all species the fiber order in the optic tract reflects the order of ganglion cell production, with older fibers deeper in the tract and newer fibers nearer the pial surface (Herrick, 1941, 1942; Gaze and Grant, 1978; Easter et al., 1981; Bunt, 1982; Reh et al., 1983). The sequence of ganglion cell production has previously been correlated with axon order in the cat's optic tract by noting that the formation of ganglion cells as distinct waves representing cells of different size classes matches the partial segregation of fibers by size in the tract (Walsh et al., 1983). We can now elaborate this correlation by pointing out 
that, just as the oldest cells of each ganglion cell class lie mainly in nasal retina, so the fibers of each fiber size class which lie deepest in the tract originate mainly in the contralateral nasal retina, forming the "pure crossed" fiber component described by Torrealba et al. (1982). Nasal-temporal differences in ganglion cell age are more pronounced in inferior retina than in superior retina (see Fig. 3, a and $c$ ), and this is reflected by a larger "pure-crossed" fiber component in the optic tract among fibers from inferior retina. Torrealba et al. (1982) interpreted this large "pure-crossed" component from inferior retina as representing the oldest fibers in the tract. Our evidence does not support this suggestion since, in fact, superior nasal retina tends to precede inferior nasal retina in the production of ganglion cells of each size class. In the ferret (a close relative of the cat) the optic tract shows a similar grouping of fibers by age. This grouping is present as optic fibers enter the tract, reflecting the orderly ingrowth of new fibers along the pial surface (Walsh and Guillery, 1982). This age-related fiber organization in the tract is then maintained through later development.

\section{References}

Bishop, P. O., W. Kozak, and G. J. Vakkur (1962) Some quantitative aspects of the cat's eye: Axis and plane of reference, visual field coordinates and optics. J. Physiol. (Lond.) 163: 503-539.

Bowling, D. B., and C. R. Michael (1980) Projection pattern of single physiologically characterized optic tract fibers in cat. Nature 286: 899902.

Boycott, B. B., and H. Wässle (1974) The morphological types of ganglion cells of the domestic cat's retina. J. Physiol. (Lond.) 204: 397-419.

Bunt, S. M. (1982) Optic fiber rearrangements in the visual pathways of the adult goldfish. J. Comp. Neurol. 206: 209-226.

Cleland, B. G., W. R. Levick, and H. Wässle (1975) Physiological identification of a morphological class of cat retinal ganglion cells. J. Physiol. (Lond). 248: 151-171.

Cooper, M. L., and J. D. Pettigrew (1979) The decussation of the retinothalmic pathway in the cat, with a note on the major meridians of the cat's eye. J. Comp. Neurol. 187: 285-312.

Cunningham, T. S., J. M. Mohler, and D. L. Giordano (1982) Naturally occurring neuron death in the ganglion cell layer of the neonatal rat: Morphology and evidence for regional correspondence with neuron death in superior colliculus. Dev. Brain Res. 2: 203-215.

Easter, S. S., A. C. Rusoff, and P. E. Kish (1981) The growth and organization of the optic nerve and tract in juvenile and adult goldfish. J. Neurosci. 1: 793-811.

Gaze, R. M., and P. Grant (1978) The diencephalic course of regenerating retinotectal fibers in Xenopus tadpoles. J. Embryol. Exp. Morphol. 44: 201-216.

Glücksmann, A. (1940) Development and differentiation of the tadpole eye. Br. J. Ophthalmol. 24: 153-178.

Goldberg, S., and A. J. Coulombre (1972) Topographical development of the ganglion cell fiber layer in chick retina. A whole mount study. J. Comp. Neurol. 146: 507-518.

Grant, P., and E. Rubin (1980) Ontogeny of the retina and optic neve in Xenopus laevis. II. Ontogeny of the optic fiber pattern in the retina. J. Comp. Neurol. 189: 593-613.

Herrick, C. J. (1941) Development of the optic nerves of Amblystoma. J. Comp. Neurol. 74: 473-534.

Herrick, C. J. (1942) Optic and postoptic systems in the brain of Amblystoma tigrinum. J. Comp. Neurol. 77: 191-353.

Hickey, T. L., D. R. Whikehart, C. A. Jackson, P. F. Hitchcock, and J. D. Paduzzi (1983) Tritiated thymidine experiments in cat: A description of techniques and experiments to define the time-course of radioactive thymidine availability. J. Neurosci. Methods 8: 139-147.

Hinds, J. W., and P. L. Hinds (1974) Early ganglion cell differentiation in the mouse retina. An electron microscope analysis utilizing serial sections. Dev. Biol. 37: 381-416.

Hinds, J. W., and P. L. Hinds (1978) Early development of amacrine cells in the mouse retina: An electron microscopic, serial section analysis. J. Comp. Neurol. 179: 277-300.

Hinds, J. W., and P. L. Hinds (1983) Development of retinal amacrine cells in the mouse embryo: Evidence for two modes of formation. J. Comp. Neurol. 213: 1-23.

Hollyfield, J. G. (1968) Differential addition of cells to the retina in Rana pipiens tadpoles. Dev. Biol. 18: 163-179.
Hollyfield, J. G. (1972) Histogenesis of the retina in the killifish, Fundulum heteroclitum J. Comp. Neurol. 144: 373-379.

Hughes, A. (1981) Population magnitudes and distribution of the major modal classes of cat retinal ganglion cell as estimated from HRP filling and a systematic survey of the soma diameter spectra for classified neurons. $J$. Comp. Neurol. 197: 303-339.

Hughes, A., and E. Wieniawa-Narkiewicz (1980) A newly identified population of presumptive microneurones in the cat retinal ganglion cell layer. Nature 284: $408-410$.

lling, R. - B., and H. Wässle (1981) The retinal projection to the thalamus in the cat: A quantitative investigation and a comparison with the retinotectal pathway. J. Comp. Neurol. 202: 265-285.

Jacobson, M. (1976) Histogenesis of retina in the clawed frog with implications for the pattern of development of retinotectal connections. Brain Res. 103: $541-545$.

Jeffery, G., and V. H. Perry (1982) Evidence for ganglion cell death during development of the ipsilateral projection in the rat. Dev. Brain Res. 2: 176180.

Johns, P. R. (1977) Growth of the adult goldfish eye. III. Source of the new retinal cells. J. Comp. Neurol. 176: 343-358.

Johns, P. R., and S. S. Easter (1977) Growth of the adult goldfish eye. Il. Increase in retinal cell number. J. Comp. Neurol. 176: 331-342.

Johns, P. R., A. C. Rusoff, and M. W. Dubin (1979) Postnatal neurogenesis in the kitten retina. J. Comp. Neurol. 187: 545-556.

Kahn, A. J. (1973) Ganglion cell formation in the chick neural retina. Brain Res. 63: 285-290.

Kelly, J. P., and C. D. Gilbert (1975) The projection of different morphological types of ganglion cells in the cat retina. J. Comp. Neurol. 163: 65-80.

Kliot, M., and C. J. Shatz (1982) Genesis of different retinal ganglion cell types in the cat. Soc. Neurosci. Abstr. 8: 815.

Leventhal, A. G. (1982) Morphology and distribution of retinal ganglion cells projecting to different layers of the dorsal lateral geniculate nucleus in normal and Siamese cats. J. Neurosci. 2: 1024-1042.

Leventhal, A. G., J. Keens, and I. Tork (1980) The afferent ganglion cells and cortical projections of the retinal recipient zone (RRZ) of the cat's "pulvinar complex." J. Comp. Neurol. 194: 535-554.

Lia, B., R. W. Williams, and L. M. Chalupa (1983) Early development of retinal specialization: The distribution and decussalion patterns of ganglion cells in the prenatal cat demonstrated by retrograde peroxidase labeling. Soc. Neurosci. Abstr. 9: 702.

Lund, R., and A. Bunt (1976) Prenatal development of central optic pathways in albino rats. J. Comp. Neurol. 165: 247-264.

Lyall, A. H. (1957) The growth of the trout retina. Q. J. Micros. Sci. 98: 101110.

Mall, F. (1893) Histogenesis of the retina in Amblystoma and Necturus. J. Morphol. 8: 415-432.

Mann, I. (1928) The regional differentiation of the vertebrate retina. Am. J. Ophthalmol. 2: 515-526.

Mann, I. (1964) The Development of the Human Eye, Grune and Stratton, Inc., New York.

Mastronarde, D. M., M. A. Thibeault, and M. W. Dubin (1984) Non-uniform postnatal growth of the cat retina. J. Comp. Neurol., 228: 598-608.

Murakami, D., M. A. Sesma, and M. H. Rowe (1982) Characteristics of nasal and temporal retina in Siamese and normal cats: Ganglion cell composition, axon trajectory, and laterality of projection. Brain Behav. Evol. 21: 67-113.

Ng, A. Y. K., and J. Stone (1982) The optic nerve of the cat: Appearance and loss of axons during normal development. Dev. Brain Res. 5: 263271.

Polley, E. H., and C. Walsh (1984) A technique for flat embedding and en face sectioning of the mammalian retina for autoradiography. J. Neurosci. Methods 12: 57-64.

Polley, E. H., C. Walsh, and T. L. Hickey (1981) Neurogenesis in the cat's retina: A study using ${ }^{3} \mathrm{H}$-thymidine autoradiography. Soc. Neurosci. Abstr. 7: 672 .

Rakic, P., and K. P. Riley (1983) Overproduction and elimination of retinal axons in the fetal rhesus monkey. Science 219: 1441-1444.

Ramón y Cajal, S. (1929) Études sur la Neurogenesé de Quelque Vertébrés, Instituto de Estudios Cientificos, Madrid.

Rapaport, D. H., and J. Stone (1984) The area centralis of the cat and other mammals: Focal point for function and development of the visual system. Neuroscience 11: 289-301

Reh, T. A., E. Pitts, and M. Constantine-Paton (1983) The organization of fibers in the optic nerve of normal and tectum-less Rana pipiens. J. Comp. Neurol. 218: 282-296.

Rodieck, R. W. (1979) Visual pathways. Annu. Rev. Neurosci. 2: 193-225. 
Rogers, A. W. (1979) Techniques of Autoradiography, Elsevier/North Holland Biomedical Press, Amsterdam.

Saito, H. -A. (1983) Morphology of physiologically identified X-, Y-, and Wtype retinal ganglion cells of the cat. J. Comp. Neurol. 221: 279-268.

Sengelaub, D. R., and B. L. Finlay (1981) Early removal of one eye reduces normally occurring cell death in the remaining eye. Science $213: 573-574$.

Sengelaub, D. R., R. P. Dolan, and B. L. Finlay (1983) An autoradiographic analysis of cell generation and cell death in the hamster retinat ganglion cell layer. Soc. Neurosci. Abstr. 9: 56

Sharma, S. C., and E. Ungar (1980) Histogenesis of the goldfish retina. J. Comp. Neurol. 191: 373-382.

Sidman, R. L. (1961) Histogenesis of mouse retina studied with thymidine${ }^{3} \mathrm{H}$. In Structure of the Eye, G. K. Smelser, ed., pp. 487-505, Academic Press, Inc., New York.

Sidman, R. L. (1970) Autoradiographic methods and principles for study of the nervous system with ${ }^{3} \mathrm{H}$-thymidine. In Contemporary Research Techniques of Neuroanatomy, S. O. E. Ebbesson and W. J. Nauta, eds., pp. 252-274, Springer-Verlag, New York.

Stone, J. (1966) The naso-temporal division of the cat's retina. J. Comp. Neurol. 126: 585-600.

Stone, J. (1978) The number and distribution of ganglion cells in the cat's retina. J. Comp. Neurol. 180: 753-773.

Stone, J., D. H. Rappaport, R. W. Williams, and L. M. Chalupa (1982) Uniformity of cell distribution in the ganglion cell layer of prenatal cat retina: Implications for mechanisms of retinal development. Dev. Brain Res. 2 231-242.
Straznicky, K., and R. M. Gaze (1971) The growth of the retina in Xenopus laevis: An autoradiographic study. J. Embryol. Exp. Morphol. 26: 67-79.

Torrealba, F., R. W. Guillery, U. Eysel, E. H. Polley, and C. A. Mason (1982) Studies of retinal representations within the cat's optic tract. J. Comp. Neurol. 211: 377-396.

Tucker, G. S. (1978) Light microscopic analysis of the kitten retina: Postnatal development in the area centralis. J. Comp. Neurol. 180: 489-500.

von Szilly, A. (1912) Über die einleitenden Vorgänge bei der ersten Entstehung der Nervenfasern in Nerven opticus. Graefes Arch. Ophthalmol. 81: $67-86$.

Walsh, C., and R. W. Guillery (1982) The development of the ferret's optic tract. Invest. Ophthalmol. Vis. Sci. (Suppl.) 22: 46.

Walsh, C., E. H. Polley, and T. L. Hickey (1982) The correlation between retinal ganglion cell production and organization of fibers in the cat's optic tract. Anat. Rec. 202: 198A.

Walsh, C., E. H. Polley, T. L. Hickey, and R. W. Guillery (1983) Generation of cat retinal ganglion cells in relation to central pathways. Nature 302: 611-614.

Wässle, H. W. R. Levick, and B. G. Cleland (1975) The distribution of the alpha type ganglion cell in the cat's retina. J. Comp. Neurol. 159: 419438.

Wässle. H., B. B. Boycott, and R. -B. Illing (1981a) Morphology and mosaic of on- and off-beta cells in the cat retina and some functional considerations. Proc. R. Soc. Lond. (Biol.) 212: 177-195.

Wässle, H., L. Peichl, and B. B. Boycott (1981b) Morphology and topngraphy of on- and off-alpha cells in the cat retina. Proc. R. Soc. Lond. (Biol.) 212: 157-175. 